\title{
Prostaglandin E2-EPI and EP2 receptor signaling promotes apical junctional complex disassembly of Caco-2 human colorectal cancer cells
}

\author{
Marcelo N Tanaka ${ }^{1}$, Bruno L Diaz ${ }^{2}$, Wanderley de Souza ${ }^{3}$ and \\ Jose A Morgado-Diaz*1
}

Address: ${ }^{1}$ Divisão de Biologia Celular, Coordenação de Pesquisa, Instituto Nacional de Câncer, Rua André Cavalcanti 37, $5^{\circ}$ Andar, Rio de Janeiro, RJ, CEP: 20230-051, Brazil, '2Laboratório Intermediário de Inflamação, Instituto de Biofísica Carlos Chagas Filho, Universidade Federal do Rio de Janeiro, Ilha do Fundão, 21941-902, Rio de Janeiro, RJ, Brazil and ${ }^{3}$ Laboratório de Ultraestrutura Celular Hertha Meyer, Instituto de Biofísica Carlos Chagas Filho, Universidade Federal do Rio de Janeiro, Ilha do Fundão, 21941-902, Rio de Janeiro, RJ, Brazil

Email: Marcelo N Tanaka - mtanaka@inca.gov.br; Bruno L Diaz - bldiaz@biof.ufrj.br; Wanderley de Souza - wsouza@biof.ufrj.br; Jose A Morgado-Diaz* - jmorgado@inca.gov.br

* Corresponding author

Published: 2 December 2008

BMC Cell Biology 2008, 9:63 doi:10.1 186/1471-2121-9-63

This article is available from: http://www.biomedcentral.com/l47I-2121/9/63

(c) 2008 Tanaka et al; licensee BioMed Central Ltd.

This is an Open Access article distributed under the terms of the Creative Commons Attribution License (http://creativecommons.org/licenses/by/2.0), which permits unrestricted use, distribution, and reproduction in any medium, provided the original work is properly cited.

\begin{abstract}
Background: The apical junctional complex (AJC) is a dynamic structure responsible to maintain epithelial cell-cell adhesions and it plays important functions such as, polarity, mechanical integrity, and cell signaling. Alteration of this complex during pathological events leads to an impaired epithelial barrier by perturbation of the cell-cell adhesion system. Although clinical and experimental data indicate that prostaglandin $\mathrm{E}_{2}\left(\mathrm{PGE}_{2}\right)$ plays a critical function in promoting cell motility and cancer progression, little is known concerning its role in AJC disassembly, an event that takes place at the beginning of colorectal tumorigenesis. Using Caco-2 cells, a cell line derived from human colorectal cancer, we investigated the effects of prostaglandin $E_{2}\left(P G E_{2}\right)$ treatment on $\mathrm{AJC}$ assembly and function.
\end{abstract}

Results: Exposition of Caco-2 cells to $\mathrm{PGE}_{2}$ promoted differential alteration of $\mathrm{AJC}$ protein distribution, as evidenced by immunofluorescence and immunoblotting analysis and impairs the barrier function, as seen by a decrease in the transepithelial electric resistance and an increase in the permeability to ruthenium red marker. We demonstrated the involvement of EPI and EP2 prostaglandin $E_{2}$ receptor subtypes in the modulation of the $A J C$ disassembly caused by prostanoid. Furthermore, pharmacological inhibition of protein kinase-C, but not PKA and P38MAPK significantly prevented the $\mathrm{PGE}_{2}$ effects on the AJC disassembly.

Conclusion: Our findings strongly suggest a central role of Prostaglandin E2-EPI and EP2 receptor signaling to mediate AJC disassembly through a mechanism that involves PKC and claudin-I as important target for the TJ-related effects in human colorectal cancer cells (Caco-2). 


\section{Background}

Tight junctions (TJs) and the subjacent adherens junctions (AJs) constitute the apical junctional complex (AJC), which is responsible to maintain the epithelial phenotype $[1,2]$. TJs form a semi-permeable diffusion barrier in an ion- and size- selective manner through the paracellular pathway and have a fence function to maintain cell polarity as a boundary between the apical and basolateral plasma membrane domains [3]. AJs are the main adhesive junctions involved in the mechanical strength of tissues [4]. Recent studies suggest that these complexes not only mediate cell-cell adhesion, but are also engaged in signal transduction [5]. E-cadherin, the main protein of AJs interacts with the cytoskeleton via association with cytoplasmic proteins, the $\alpha-, \beta$ - and p120-catenins. Whereas $\beta$-catenin associated with E-cadherin at the plasma membrane regulates cell-cell adhesion, cytoplasmic $\beta$-catenin is involved in signal transduction and activation of genes, which play important roles in the development and progression of colorectal carcinoma [6]. The role of TJ proteins is less understood in this context. A number of integral membrane proteins associated with TJs have been identified during recent years. These include occludin, junctional adhesion molecule (JAM) and the claudin family consisting of at least 24 members. PDZ proteins of the MAGUK family are other integrant proteins of TJs, which are localized at the membrane-cytoskeleton interfaces of cell-cell contacts. They include the zonula occludens proteins ZO-1, ZO-2 and ZO-3, which are potentially involved in cell signaling $[7,8]$. The role of $\mathrm{ZO}-1$ protein is related to the interaction with the transcriptional factor ZONAB, known to regulate many events such as growth and proliferation [9].

Prostaglandins (PGs) are bioactive lipid molecules produced by the cyclooxygenase enzymes COX-1 and COX-2, and exert diverse physiological actions in the gastrointestinal tract including maintenance of mucosal integrity, regulation of secretion and cell motility [10]. Clinical and experimental data indicate that prostaglandin $\mathrm{E}_{2}\left(\mathrm{PGE}_{2}\right)$ plays a predominant role in promoting cancer progression. It was reported that $\mathrm{PGE}_{2}$ stimulates EP receptor signaling with subsequent enhancement of cellular proliferation, promotion of angiogenesis, inhibition of apoptosis, stimulation of invasion/motility of colon cancer cells, as well as tumorigenic potential in intestinal epithelial cells $[11,12]$. It has been reported that both COX-2 and the epidermal growth factor receptor (EGFR) are activated in most human cancers. The observation that forced expression of COX-2 in human colorectal cancer (CRC) cells stimulates proliferation through EGFR activation, suggests the likelihood of a cross talk between these two pathways $[13,14]$. In a previous study we have demonstrated a link between the PKC, EGFR and MAPK path- ways to modulate the loss of E-cadherin dependent cellcell adhesion in Caco-2 cell [15].

$\mathrm{PGE}_{2}$ has also been implicated in direct EGFR activation through intracellular phosphorylation of receptor tyrosine kinase or extracellular release of a membrane-bound EGFR ligand, such as heparin-binding EGF in human colorectal cancer cells [16]. However, the involvement of EP receptor subtypes in these studies has been not reported. Furthermore, it was shown in LS174T, a human colorectal cancer cell line, that $\mathrm{PGE}_{2}$ induces expression of amphiregulin, an EGFR ligand, through a Protein Kinase A (PKA)-dependent mechanism [11]. Although it is known that $\mathrm{PGE}_{2}$ is the ligand to four EP receptors subtypes called EP1, EP2, EP3 and EP4, which are the products of separate genes $[17,18]$, the lack of information concerning the role that each EP receptor plays hinders the understanding of $\mathrm{PGE}_{2}$-mediated gastrointestinal physiology alterations. Moreover, the precise role of each EP in the malignant behavior remains to be defined. Some studies have reported the participation of the EP1 and EP4 receptor in promoting tumorigenic behavior in colon carcinogenesis $[12,19,20]$ and downregulation of subtype EP3 during colon cancer development [21]. However, the identification of EP modulating epithelial barrier function through mediation of AJC disassembly events has not been reported.

The aim of the present study was to investigate the response of Caco-2 cells to treatment with $\mathrm{PGE}_{2}$. We hypothesized that PGE2 would impair the AJC assembly and function of Caco-2 cells. We examined AJC protein distribution, paracellular permeability and identified the involvement of EP receptors as well as cell signaling pathways in response to prostanoid treatment. We report in this study that treatment with $\mathrm{PGE}_{2}$ caused a transient AJC disassembly through a network involving EP1 and EP2 receptors and PKC signaling with claudin-1 as target related to TJs effects in the human colon cancer cells, Caco-2.

\section{Results \\ Prostaglandin E2 treatment causes a differential redistribution of the $A J C$ proteins}

Initially, we analyzed the distribution of the AJC proteins after treatment with $\mathrm{PGE}_{2}$ by immunofluorescence microscopy using antibodies against E-cadherin, $\beta$-catenin, claudin-1, occludin and ZO-1. Figure 1 shows a continuous and intense labeling at the cell-cell contact region for all proteins used in non-treated cells. After $\mathrm{PGE}_{2}$ treatment, it was possible to observe alterations in the immunostaining pattern of AJC proteins with exception of ZO1 that remained at the membrane. After $15 \mathrm{~min}$ of treatment E-cadherin appears in a discontinuous and irregular 
control
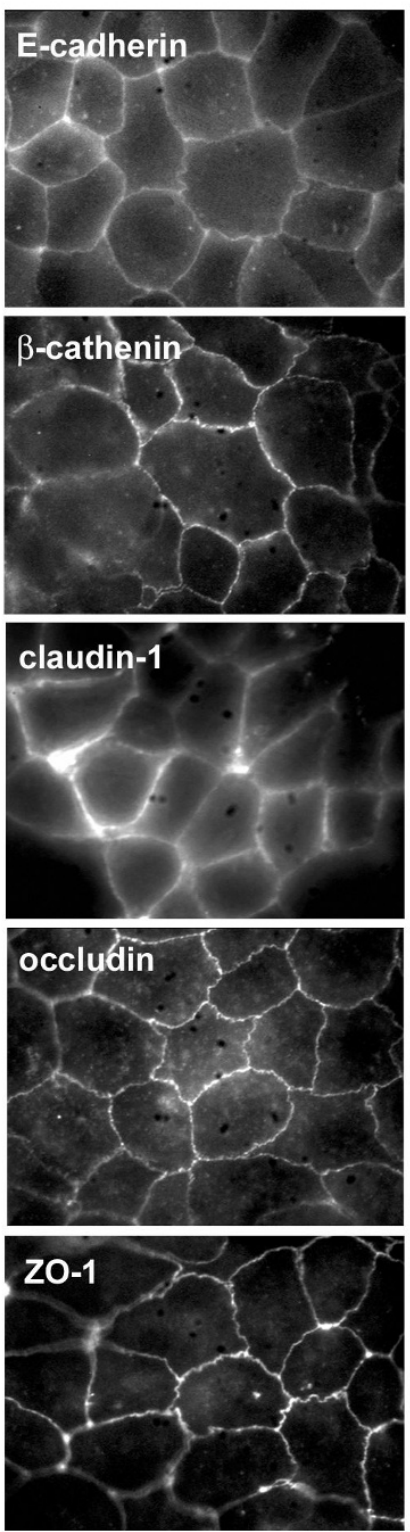

15
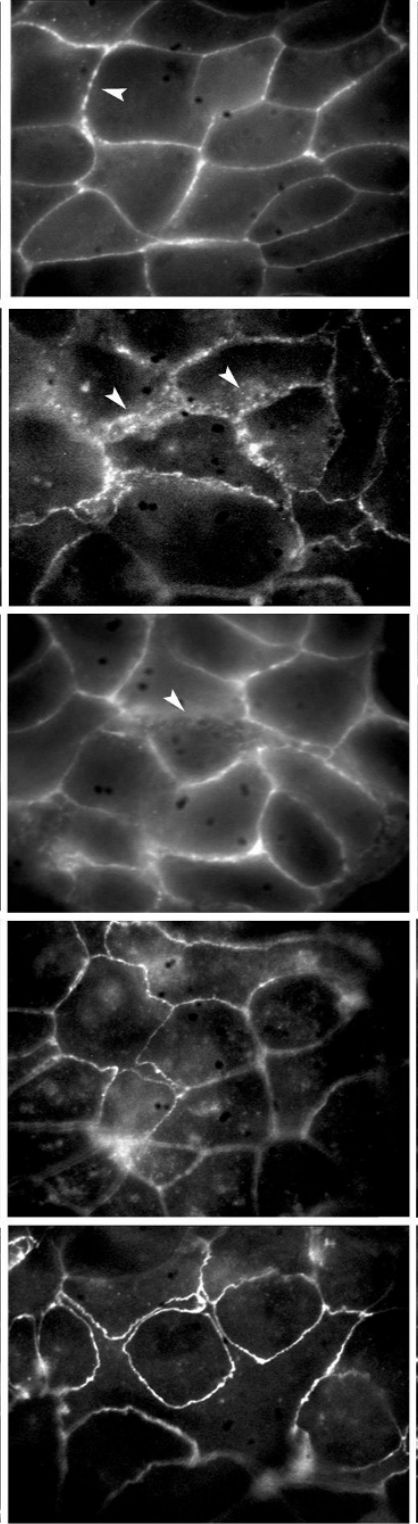

$30^{\prime}$
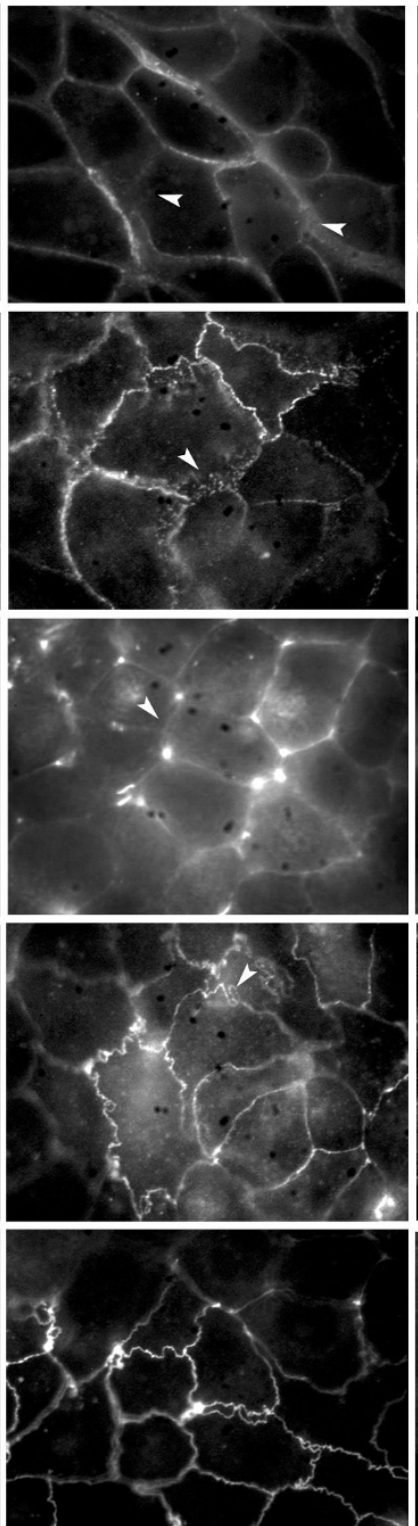

$60^{\prime}$
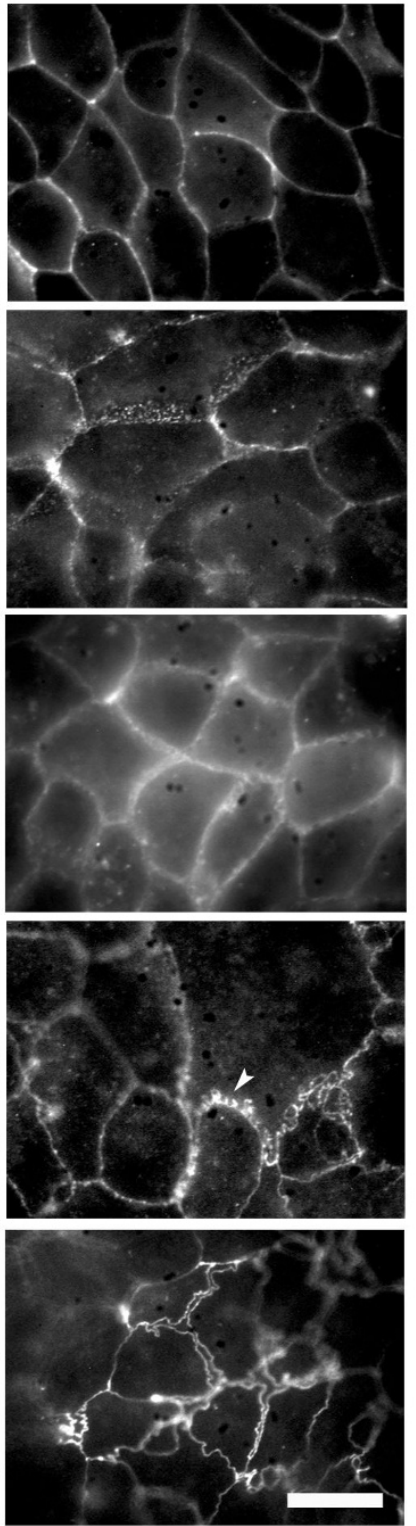

Figure I

Prostaglandin E2 treatment causes a differential redistribution of the AJC proteins. Caco-2 cells were grown on sterile glass coverslips and after $\mathrm{PGE}_{2}$ treatments they were processed for immunofluorescence analysis using specific antibodies of AJC proteins, as indicated. Images show control $(0 \mathrm{~min})$ and treated for I5, 30 and 60 min treatments with I $\mu$ M PGE 2 . Note that - with the exception of ZO-I - E-cadherin, $\beta$-catenin, claudin-I and occludin showed alterations of the staining pattern at 15 and 30 min of treatment. An apparent recovery of the labeling was observed at 60 min for E-cadherin, $\beta$-catenin and claudin- I, but not for occludin that showed membranous projections to the cytoplasm. Bar: $10 \mu \mathrm{m}$

string-of beads-shape at the cell-cell contacts. At $30 \mathrm{~min}$ internalization into the cytoplasm was observed but at 60 min there was a significant recovery of the labeling pattern. $\beta$-catenin at $15 \mathrm{~min}$ also showed a discontinuous and irregular labeling at the membrane with projections to the cytoplasm; at $30 \mathrm{~min}$ and $60 \mathrm{~min}$ of treatment it appears with minor translocation into the cytoplasm, however a considerable amount of the protein was still at the membrane. Immunostaining of claudin-1 at $15 \mathrm{~min}$ showed a discontinuous membranous staining in same 
regions of cell-cell contact and at 30 min this effect was more evident with strong points of labeling and a weak or absent staining in the cell-cell contact area. At $60 \mathrm{~min}$ there was a labeling recovery at the cell-cell contacts. Occludin appears with no alterations at $15 \mathrm{~min}$, however after 30 and 60 min of treatment projections in the direction of the cytoplasm mainly at 60 min, were observed.
We further analyzed the subcellular distribution of AJC proteins by immunoblotting using soluble and insoluble TX-100 fractions after PGE $_{2}$ treatment (Figure 2). The distribution pattern and densitometry analysis of the AJ proteins, $\beta$-catenin, and E-cadherin showed a significant translocation from the insoluble fraction to the soluble in cells that were treated for 15 min with $\mathrm{PGE}_{2}$ (Figures $2 \mathrm{~A}$
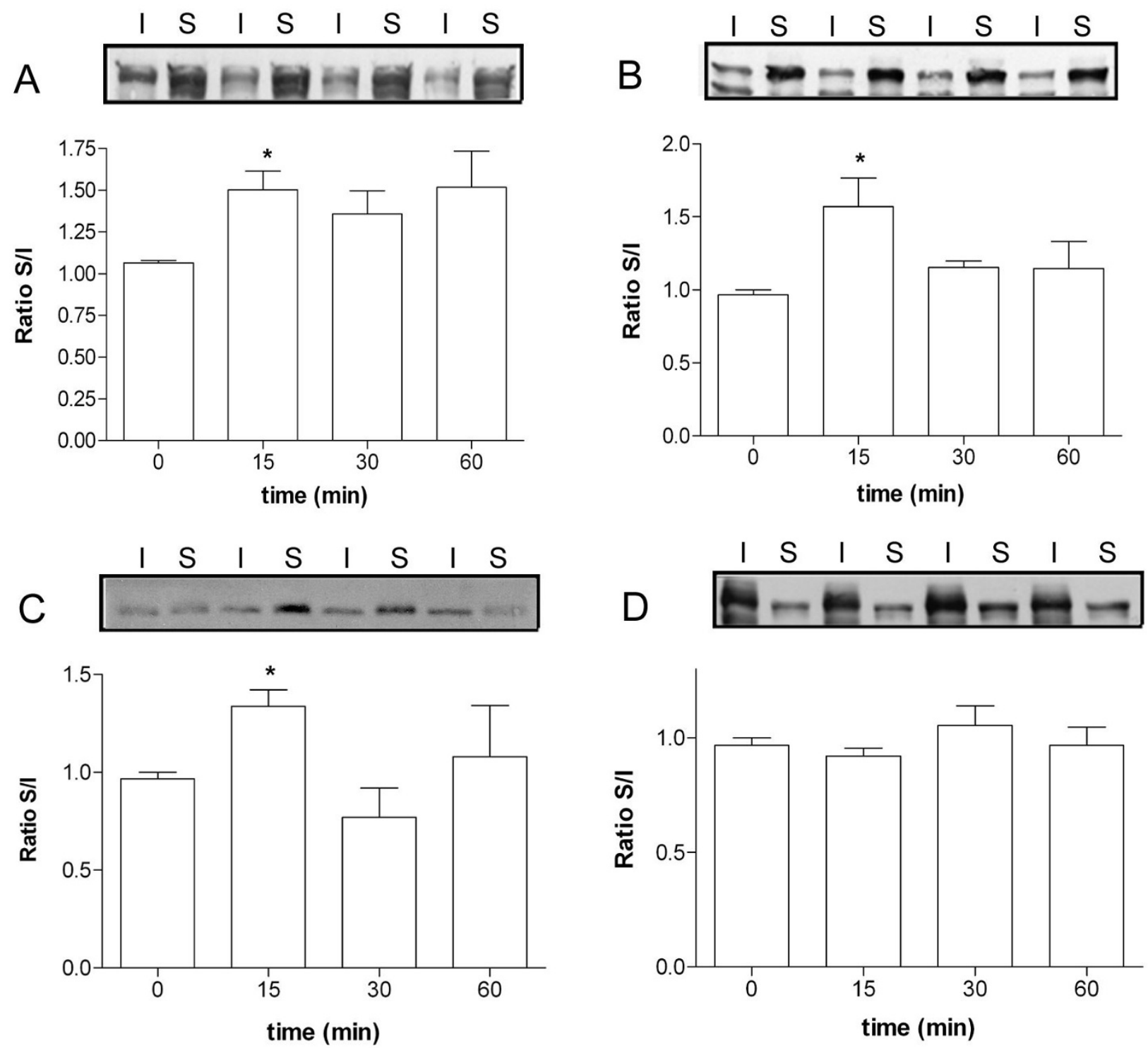

Figure 2

PGE $_{2}$ treatment alters the TX- 100 solubility of AJC proteins in Caco-2 cells. Representative immunoblots and densitometric analysis of E-cadherin (A), Beta-catenin (B), claudin-I (C) and occludin (D) of insoluble (I) and soluble (S) fractions in Triton X-100 of cells that were untreated $(0 \mathrm{~min})$ or treated for I5, 30 and 60 min with I $\mu$ M PGE2. In each case the score was calculated using the following equation: Arbitrary score= (amount of the protein in the soluble fraction)/(amount of the protein in the insoluble fraction). The score for untreated cells $(0 \mathrm{~min})$ was normalized as $I$ in each case. Average scores S.E.M of three independent experiments are shown. Significantly different: $*(P<0.05)$. 

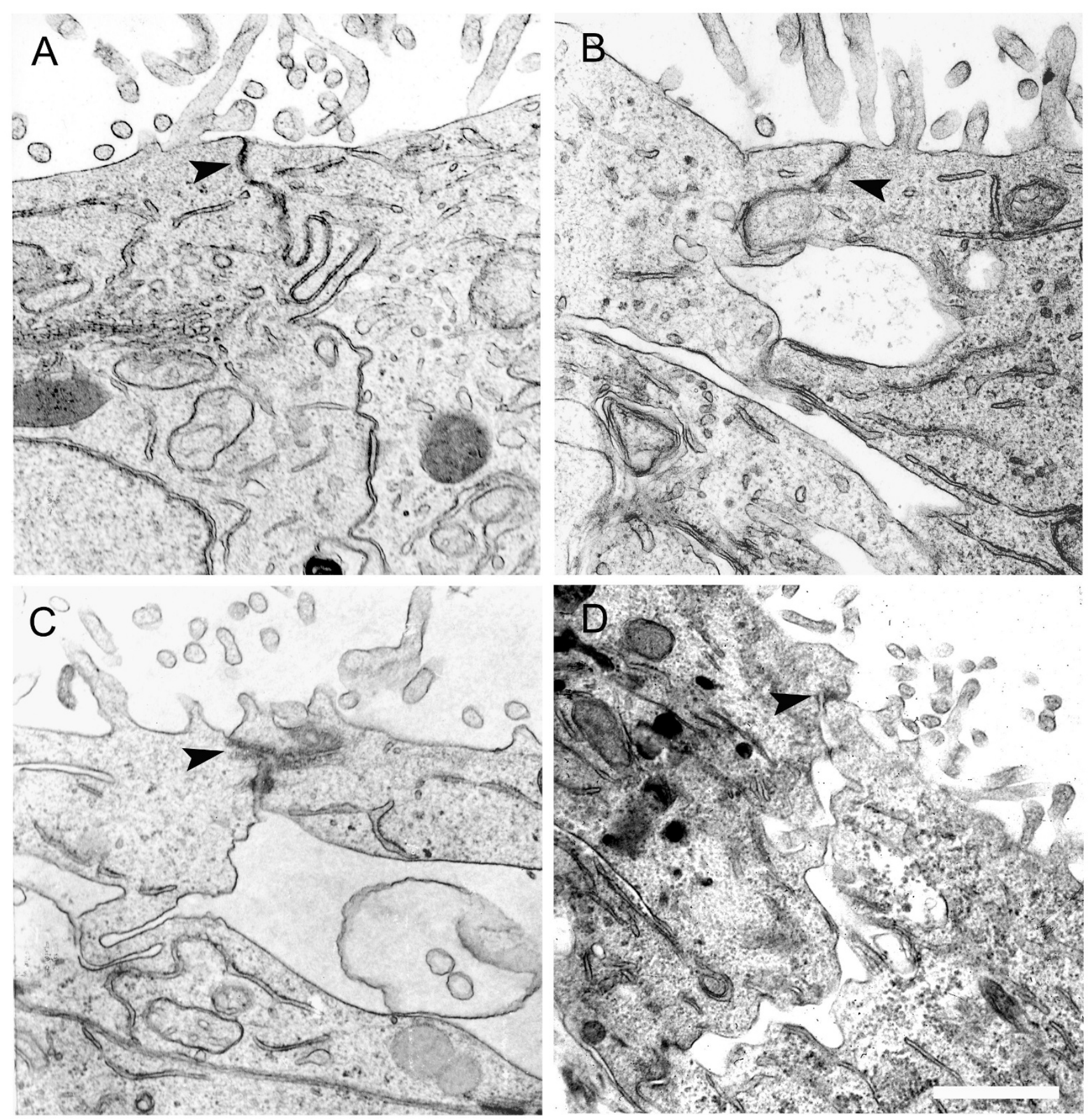

\section{Figure 3}

$\mathbf{P G E}_{2}$ treatment influences the AJC ultrastructural characteristics of Caco-2 cells. Caco-2 cells were grown on Transwell filters until they achieved confluence, treated with I $\mu \mathrm{M} \mathrm{PGE}_{2}$ and processed for electron microscopy analysis. Representative images of thin sections of control cells $(A)$ shows an intact AJC between two neighbor cells, however cells treated with $\mathrm{PGE}_{2}$ for $\mathrm{I} 5$ (B), 30 (C) and 60 (D) show alterations in the $\mathrm{AJC}$ region, mainly at the adherent junction area. Note that the TJ (Arrowheads) apparently remain unaltered. Bar: $2.5 \mu \mathrm{m}$. TJs: Tight Junctions. 
and $2 \mathrm{~B}$, respectively). In a similar manner, this same effect was observed for the TJ proteins, claudin-1 but not for occludin (Figures 2C and 2D). Together these results indicate that $\mathrm{PGE}_{2}$ treatment caused a differential redistribution of the AJC proteins.

\section{$P G E_{2}$ induce ultrastructural $A J C$ alterations with concomitant loss of $\mathrm{T} J$ functionality}

We examined morphological alterations of AJC caused by $\mathrm{PGE}_{2}$ treatment using transmission electron microscopy (Figure 3). Non-treated Caco-2 cells form a well-organized monolayer with a typical junctional complex in the apical region and exhibit numerous microvilli (Figure $3 \mathrm{~A})$. When cells were exposed to $1 \mu \mathrm{M}$ of $\mathrm{PGE}_{2}$, wide spaces at the sub apical cell-cell contact region were visible after 15 and $30 \mathrm{~min}$ and at $60 \mathrm{~min}$ there was an apparent recovery of the AJC. Although alterations well pronounced at the $\mathrm{AJ}$ area was observed, the TJ region apparently remained intact during the $\mathrm{PGE}_{2}$ treatment (Figures 3B, C and 3D).

In order to verify $\mathrm{TJ}$ functionality after $\mathrm{PGE}_{2}$ treatment, the epithelial barrier function was assessed in individual cell junctions, using the ruthenium red technique and electron microscopy and in the cell monolayers by monitoring the TER. As seen in Figure 4, ruthenium red added to the apical region did not permeate through the TJs of untreated cells, but it permeated through the paracellular space in cells treated with $\mathrm{PGE}_{2}$, both at 15 and $30 \mathrm{~min}$. Next, the permeability to ions of confluent Caco- 2 cells was assessed by TER measurements, which showed a value of about $400 \Omega \mathrm{cm}^{2}(100 \%)$ in untreated cells. However, $\mathrm{PGE}_{2}$ treatment caused a significant drop of the TER (41\% and $36 \%$ ) after 15 and $30 \mathrm{~min}$, respectively, but after 60 and 120 min there was a recovery. Additionally, using 16, 16-dimethyl Prostaglandin $E_{2}\left(16,16-d m P^{2} E_{2}\right)$, a synthetic analogue of $\mathrm{PGE}_{2}$, we confirmed similar effects to those observed when cells were treated with $\mathrm{PGE}_{2}$ (Figure $4 \mathrm{~B})$.

\section{Identification of Prostaglandin $E_{2}$ Receptor Subtypes EP involved in the AJC disassembly}

$\mathrm{PGE}_{2}$ is known to interact with four different types of cell surface prostaglandin E receptors (EP1, EP2, EP3 and EP4), which in turn activate different signaling pathways [10]. In the present study we identified PGE $_{2}$ Receptor Subtypes EP involved in AJC disassembly using butaprost, an EP2 specific receptor agonist and sulprostone and 17phenyl trinor, both EP1 and EP3 agonist receptors and by TER measurements (Figure 5). Butaprost, sulprostone and 17-phenyl trinor were seen to cause a significant TER decrease after 15 and 30 min of treatment when compared to non-treated cells, however after 60 and $120 \mathrm{~min}$ there was a reverse effect on the TER measurements. It is important to emphasize that although sulprostone and 17-phe- nyl trinor $\mathrm{PGE}_{2}$ are $\mathrm{EP} 1$ and $\mathrm{EP} 3$ receptor agonists, in the concentration here used $(1 \mu \mathrm{M})$, they have a higher affinity for the EP1 receptor [22-24]. This result was similar when the cells were treated with $\mathrm{PGE}_{2}$ or with its analogue, $\left(16,16-\mathrm{dm} \mathrm{PGE}_{2}\right)$, which indicates the involvement of EP1 and EP2 receptors in a transient AJC disassembly mediated by $\mathrm{PGE}_{2}$.

\section{$\mathrm{PGE}_{2}$ module AJC disassembly through PKC signaling}

There are no data about the cell-cell adhesion mechanisms mediated by $\mathrm{PGE}_{2}$, nor information concerning the signaling pathways involved in this event Thus, we decided to investigate downstream cell signaling mechanisms triggered by the EP receptors after $\mathrm{PGE}_{2}$ treatment (Figure 6). When cells were pretreated with SB203580, an inhibitor of p38 MAPK, it was possible to observe that the inhibitor did not prevent the drop of the $\mathrm{PGE}_{2}$ - induced TER. Incubation of Caco- 2 cells with H-89, a PKA blocker, did not prevent the TER decrease after 15 and $30 \mathrm{~min}$ of $\mathrm{PGE}_{2}$ treatment, but abolished the gradual TER re-stabilization promoted after 60 and $120 \mathrm{~min}$. It is important to point out that, although the $\mathrm{IC}_{50}$ of $\mathrm{H}-89$ for PKA is 48 or $135 \mathrm{nM}$ [25], we used the concentration of $20 \mu \mathrm{M}$ on the basis of previous studies showing that it is also able to inhibit PKA activity in culture cells [26,27]. Next, we verified if PKC is involved in this event and observed that pretreatment with Calphostin $\mathrm{C}$, a well-known inhibitor of novel and conventional PKC isoforms, prevented the TER drops at all assessed times (Figure 6A). We further confirmed this later result by immunoblotting and immunofluorescence analysis using claudin-1, a TJ protein known to be involved in the regulation of the paracellular permeability [28]. Figures $6 \mathrm{~B}$ and $6 \mathrm{C}$ show the reversible effect on the translocation to the TX-soluble fraction and redistribution of this protein through pretreatment with Calphostin $C$ prior to incubation for 15 min with $\mathrm{PGE}_{2}$. In parallel, we also verified the effect of Calphostin $\mathrm{C}$ on the ultrastructural status of the AJC and TJ functionality using the ruthenium red marker. In Figure 6D it is possible to see that pretreatment with the PKC inhibitor completely blocked the permeation of the marker through the paracellular space caused after treatment for 15 and $30 \mathrm{~min}$ with $\mathrm{PGE}_{2}$. The ruthenium red in cells pretreated with Calphostin $\mathrm{C}$ was restricted at the apical region in a similar manner as in untreated cells. Taken together these results indicate that PKC is involved in the modulation of the AJC disassembly in $\mathrm{PGE}_{2}$ - stimulated Caco-2 cells.

\section{Discussion}

The loss of the AJC assembly by deleterious inflammatory mechanisms is an important problem in intestinal physiology due to the contribution of this structure to the maintenance of cell-cell adhesion. $\mathrm{PGE}_{2}$ has been implicated in essential physiological processes in the colon such as electrolyte transport, cell motility and in the 


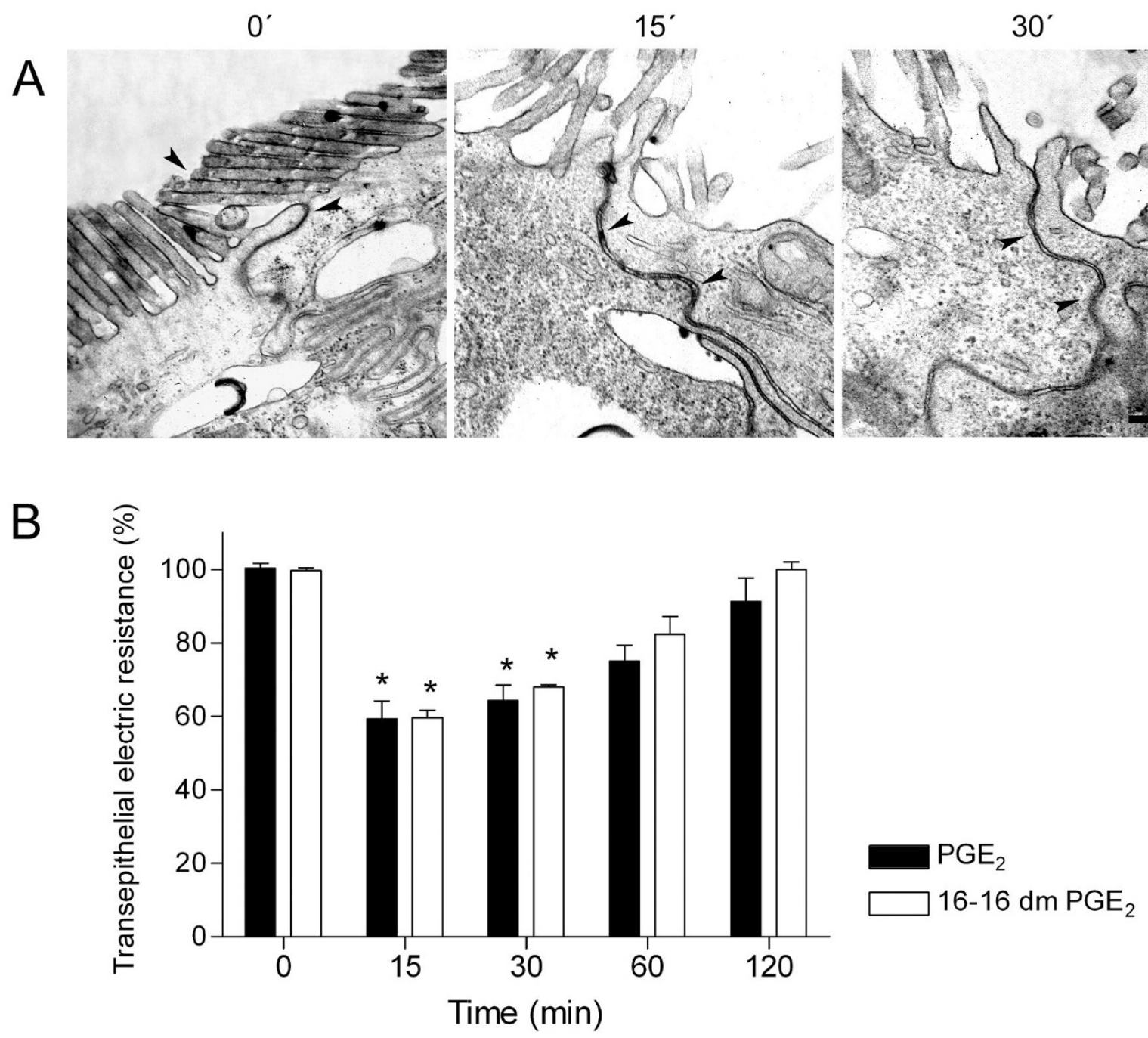

\section{Figure 4}

$\mathbf{P G E}_{2}$ affect the paracellular permeability in Caco-2 cells. Cells were cultured on Transwell polycarbonate filters and the TJ functionality was analyzed by the ruthenium red technique $(A)$ and by measuring the Transepithelial electrical resistance (TER) (B). A: Representative images of thin sections of control cells showing the ruthenium red in the apical region in control cells and in cells treated with $\mathrm{PGE}_{2}$, as indicated. Cells incubated with the prostanoid revealed extensive spaces in the junctional complex area and permeation of the marker between the intercellular spaces. Bar: $0.8 \mu \mathrm{m}$. Arrowheads: ruthenium red. $\mathrm{B}$. TER was measured in different conditions as indicated. Observe that $P_{\text {GE }}$ and its analogue, PGE $16-16 \mathrm{dm}_{2} \mathrm{PGE}_{2}$, caused a significant drop of the TER ( $* P<0.01$ compared with untreated cells). The effect was visible at I5 and 30 min, however at 60 and 120 min a recovery of the TER was observed.

pathogenesis of inflammatory bowel diseases where increased levels of $\mathrm{PGE}_{2}$ are observed in inflamed tissue [17]. Also, $\mathrm{PGE}_{2}$ has been reported as having a role in intestinal tumorigenesis [29]. Thus, there is strong evidence indicating a link between AJC regulation, intestinal inflammation and tumorigenesis. However the mechanisms underlying the $\mathrm{PGE}_{2}$ effects on AJC disassembly, a pivotal event at the beginning of the colorectal tumorigenesis, remain to be elucidated.
The results reported here show that $\mathrm{PGE}_{2}$ treatment caused transient differential redistribution of the AJC proteins in Caco-2 cells. We observed, by immunofluorescence, that $\mathrm{AJ}$ proteins, $\beta$-catenin and E-cadherin undergo significant alteration in localization. Similarly, TJ proteins claudin-1 and occludin showed an apparent redistribution from cell-cell contacts to the cytoplasm; however ZO1 remained unaltered. By immunoblotting it was possible to observe a significant increase in the soluble TX-100 


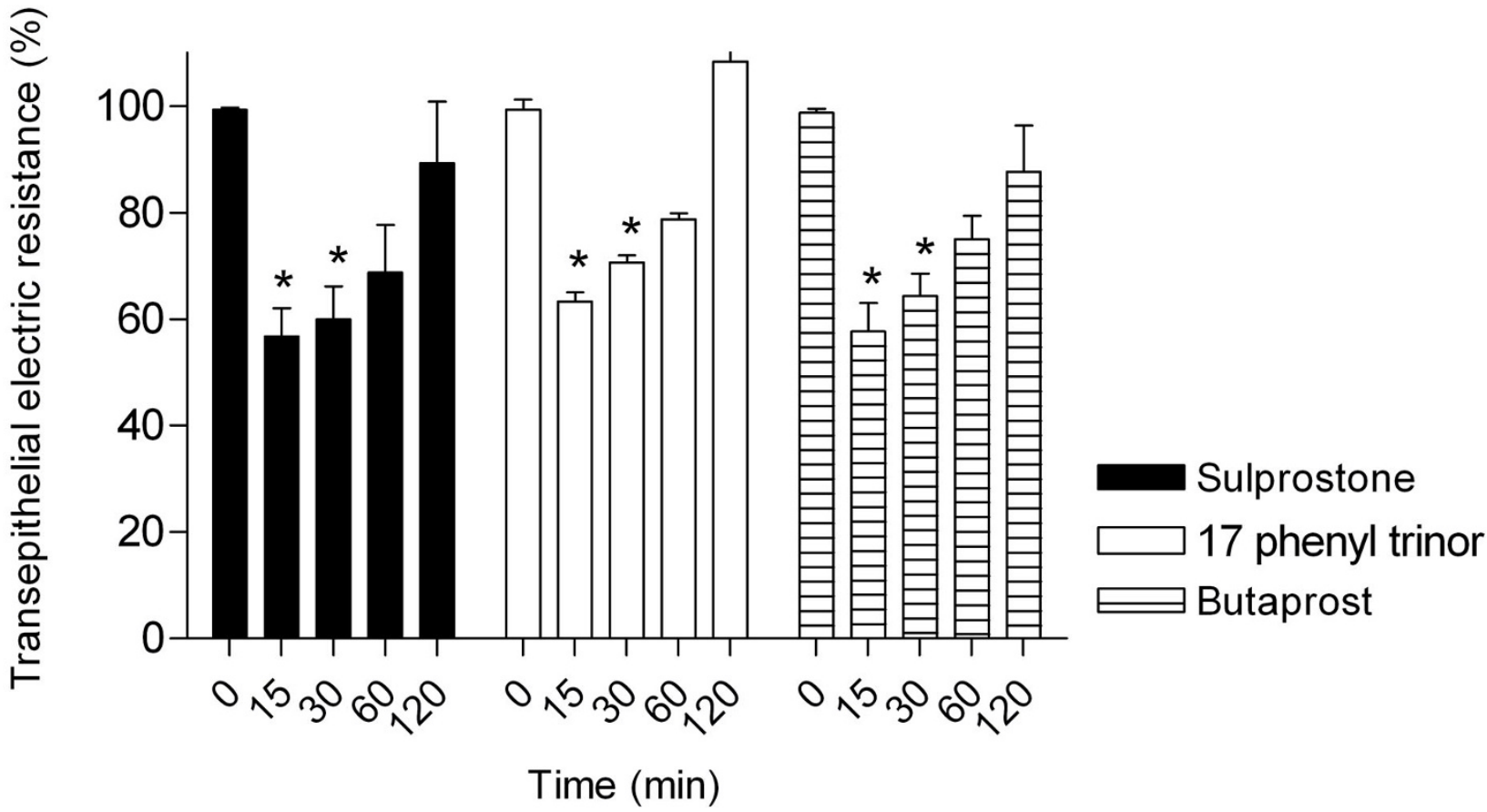

Figure 5

Effects of EP agonists on the transepithelial electric resistance. Caco-2 cells were grown to confluence on Transwell polycarbonate filters and the TER was measured before and after treatment with agonists. All the agonists caused a drop of the TER at 15 and $30 \mathrm{~min}$ and at 60 and $120 \mathrm{~min}$ a recovery was observed. S.E.M of three independent experiments are shown. Significantly different: * $(\mathrm{P}<0.05)$.

fraction of $\beta$-catenin, E-cadherin and claudin-1, but not for occludin. Furthermore, electron microscopy analysis of the subapical AJC region revealed wide spaces in this area in response to $\mathrm{PGE}_{2}$, but the TJ regions apparently remained unaltered. Concomitantly to these results, we showed a significant decrease of the TER, as well as increased permeation to ruthenium red marker in cells treated with $\mathrm{PGE}_{2}$. Since TJs are largely responsible for regulating paracellular permeability [30-32] it is probably that $\mathrm{PGE}_{2}$ acts directly against the components of these structures. The distribution analysis of claudin-1 tends to support this conclusion, since the translocation of this protein from the TX-100 insoluble fraction (cytoskeletonlinked proteins) to the TX-100 soluble fraction (cytoplasmic proteins) is associated with the drop of the TER and permeation to ruthenium red in response to $\mathrm{PGE}_{2}$. Several groups have described the involvement of pro-inflammatory cytokines, such as TNF $\alpha$ and interferon- $\gamma$, on AJC proteins and barrier function modulation $[33,34]$. In relation to $\mathrm{PGE}_{2}$, only one study carried out by Martin-Venegas et al., [35] reported increased paracellular permeability when differentiated Caco- 2 cells were stimulated with $\mathrm{PGE}_{2}$. Nevertheless, in this study the AJC pro- tein distribution was not carried out, different $\mathrm{PGE}_{2}$ concentrations were used and paracellular permeability alteration was only evidenced after $2 \mathrm{~h}$ of treatment. In our work here we also reported altered cytoskeletonlinked claudin-1, as evidenced by their translocation to TX-100 soluble fraction in $\mathrm{PGE}_{2}$-treated cells, corroborating with the paracellular permeability alteration. This result is consistent with studies showing that alterations in distribution or expression of claudin-1 play an important role in epithelial barrier function [36-38]. Adaptor ZO proteins have been documented as being responsible for the connection between claudins and the actin cytoskeleton [7]. The fact that we did not find distribution differences of ZO-1 in $\mathrm{PGE}_{2-}$ treated cells, suggests that other adaptor proteins, not investigated here, could be mediating this linkage.

Prostanoids such as $\mathrm{PGE}_{2}$ exert their biological action through binding to four specific membrane receptors the subtypes EP1 to EP4 that are G protein-coupled receptors [29]. The expression and involvement of these receptors in colorectal cancer has been reported $[19,20,29]$; however it is not known whether these receptors are 
A

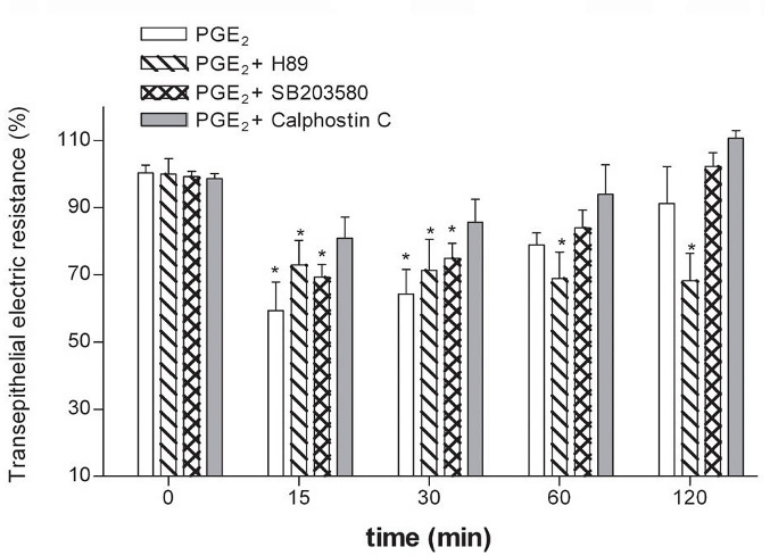

C

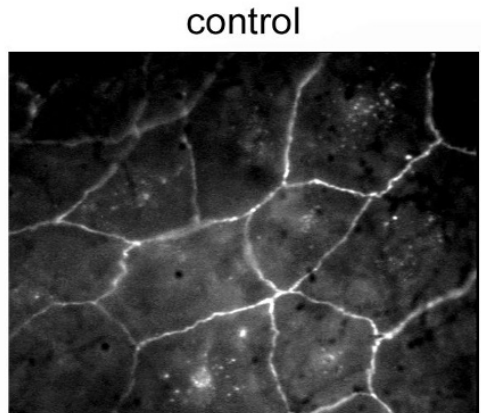

0

D

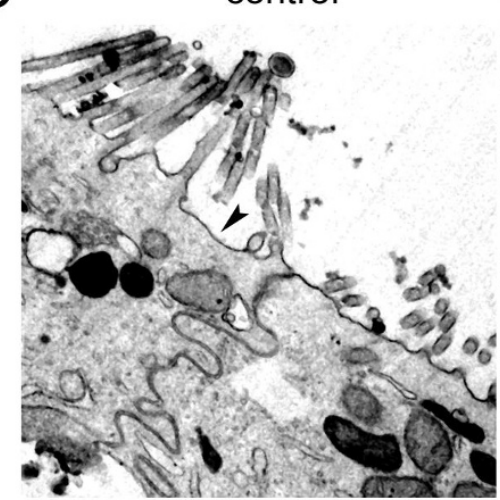

$0^{\prime}$
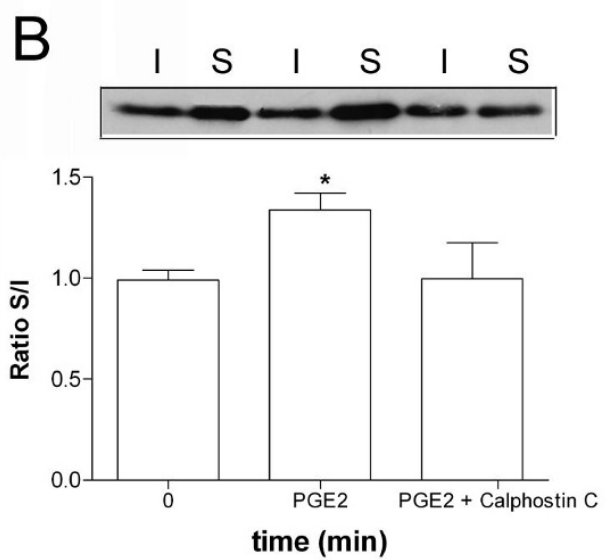

PGE2 + Calphostin C

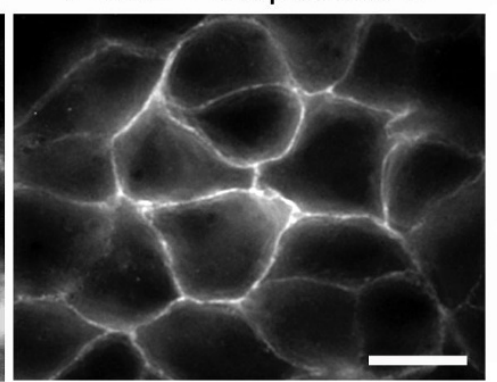

$15^{\prime}$

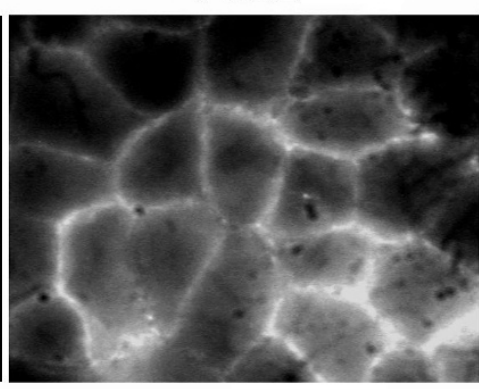

$15^{\prime}$

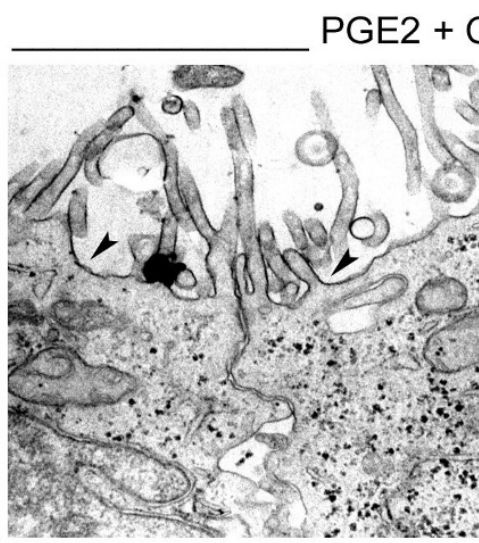

$15^{\prime}$

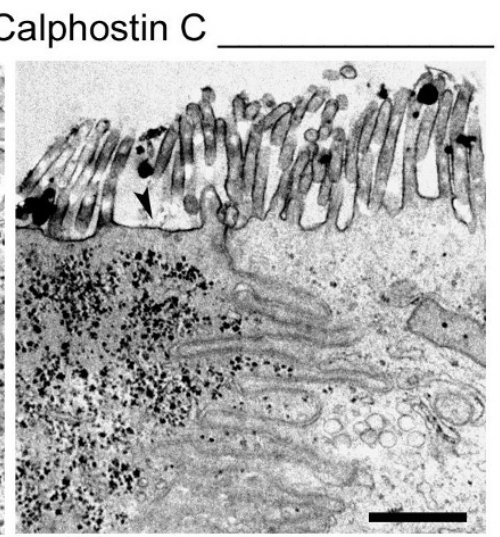

$30^{\circ}$

\section{Figure 6}

PKC inhibition reverts the effect on the redistribution of Claudin-I and the paracellular permeability caused by $\mathbf{P G E}_{2}$. The TER was measured before and after treatment with I $\mu \mathrm{M}$ PGE 2 and pretreated for I h with H-89, SB203580 and Calphostin C. Note that the decrease of the TER was PKC-dependent and H-89 abrogated the TER recovery at 60 and I20 $\min (\mathrm{A})$. Caco-2 cells were grown until confluence treated or pretreated with Calphostin $\mathrm{C}$, prior to incubation with I $\mu \mathrm{M}$ $\mathrm{PGE}_{2}$ and the redistribution of Claudin-I was assessed by immunoblotting $(B)$ and immunofluorescence $(C)$. The effect of pretreatment with the inhibitor was also analyzed by using the ruthenium red technique and electron microscopy (D). Observe that PKC inhibition was able to block alterations caused by PGE 2 . Bars in B: $10 \mu \mathrm{m}$ and in D: I.2 $\mu \mathrm{m}$. 
involved in the regulation of the AJC disassembly and consequently contribute to carcinogenesis colorectal. Here, we showed the involvement of $\mathrm{PGE}_{2}$ receptor subtypes EP1 and EP2 in mediating AJC disassembly. This hypothesis is supported by the observation that 17-phenyl trinor $\mathrm{PGE}_{2}$, butaprost, and sulprostone caused a significant decrease in the TER at 15 and $30 \mathrm{~min}$ in a similar manner to $\mathrm{PGE}_{2}$ and its analogue. It has been reported that both, sulprostone and 17-phenyl trinor $\mathrm{PGE}_{2}$ are EP1 and $\mathrm{EP} 3$ receptor agonists, however in the concentration of $1 \mu \mathrm{M}$ used in the present study, they have a higher affinity for the EP1 receptor $[22,39,40]$. Since previous results show that Caco- 2 cells express only EP1 and EP2 subtypes of $\mathrm{PGE}_{2}$ receptors [41], we suggest that $\mathrm{PGE}_{2}$ mediates AJC disassembly through EP1 and EP2 receptors in this cell line.

It is known that EP2 receptors are coupled to PKA/adenyl cyclase and mediate the increase of intracellular cAMP [41] whereas ligand binding of EP1 is associated with phospholipase $\mathrm{C}$ and PKC activation [42]. On the other hand, studies have demonstrated the involvement of various cell signaling pathways such as: PKC, PKA, MAPK, and PI3K/Akt in the regulation of the TJ barrier function [7]. In our $\mathrm{PGE}_{2}$ stimulation model using Caco-2 cells, we found that $\mathrm{PGE}_{2}-\mathrm{EP} 1$ and -EP2 receptor signaling to decrease TER was predominantly linked to the PKC pathway, but not to PKA or p38MAPK. It is known that PKC has long been recognized to affect epithelial and endothelial barriers. This kinase consists of a family of Ser/Thrspecific kinases, which includes 12 known isozymes that can be classified into three subfamilies: conventional $(\alpha$, $\beta 1, \beta 2$ and $\gamma)$, novel $(\delta, \varepsilon, \theta, \varepsilon$ and $\mu)$ and atypical $(\lambda, \tau$ and $\zeta$ ), which differ in their mechanism of action, subcellular distribution, substrate type and expression [7]. In addition, several studies using different agents that perturb the epithelial junctional complex have demonstrated the involvement of various kinases in the phosphorylation and regulation of claudin proteins, however the mechanisms underlying this effect remain largely unknown. In relation to PKC, a recent study using three complementary molecular approaches and Caco-2 cells showed that the PKC- $\theta$ isoform plays various novel mechanisms in intestinal epithelium, namely: alterations of the claudin- 1 and claudin- 4 isotypes phosphorylation, membrane assembly, and distribution as well as permeability function in cell monolayer [38]. If this PKC isoform is responsible to mediate alteration in claudin-1 in Caco-2 cells treated with PGE2, remain to be elucidated. It is an important addition to studies on cell signaling mechanisms involving EP receptors in colorectal cancer that are usually aimed at analysing proliferation or apoptosis events, but not epithelial cell barrier function. For instance, it was reported that in an EP4 receptor expres- sion model with HEK293 cells, cAMP signalling appears to play a minor role in proliferation [41]. By contrast, cAMP-dependent suppression of apoptosis by $\mathrm{PGE}_{2}$ seems to occur by a mechanism dependent on ERK and p38MAPK signaling, but not PKA [43]. Also, PGE $_{2}-$ dependent EGFR activation in human colorectal cancer cells appears to be variable, with responsive (LS-174) and unresponsive (DLD-1) cell lines described [16,44]. Recently, using a model of EP4 receptor overexpression in HT-29 cells, it was shown that PGE $_{2}$-EP4 receptor signaling was linked predominantly to CAMP signaling and in low level to ERK activation, but not PKB/AKT signaling [20]. There is a clear significant heterogeneity of signaling pathways mediating $\mathrm{PGE}_{2}$ activities in different colorectal cells and the interplay between EP receptor subtypes, which are variably present on different colorectal cancer cell lines, may explain this event. Interestingly, we did not find PKA involvement in TER decrease, however it is recognized that cAMP can also signal in a PKA-independent manner via the cAMP-dependent guanine nucleotide exchange factor Epac1, which in turn activates Ras-GTPase Rap1 [45]. Additional studies are needed to elucidate if Epac 1 is involved in EP1 and EP2 receptor signaling pathways mediated by $\mathrm{PGE}_{2}$. Moreover, the fact that $\mathrm{H}-89 \mathrm{did}$ prevented TER recovery after 60 and 120 min of treatment with $\mathrm{PGE}_{2}$, suggests that PKA activation is necessary for AJC restoration, which is consistent with data showing that PKA is related to positive regulation of cell-cell and cell-substrate adhesion [46].

In summary, we have shown that $\mathrm{PGE}_{2}$ can affect $\mathrm{AJC}$ architecture and function and that at least part of this effect is mediated through PKC activation in an event that requires the participation of $\mathrm{EP} 1$ and $\mathrm{EP} 2$ receptors and claudin-1 as an important target of PKC for the TJ-related effects.

\section{Conclusion}

In this study we analyzed cell signaling mechanisms underlying $\mathrm{PGE}_{2}$ treatment on the Apical Junctional Complex assembly and function in a human colon cancer cell model. Using a physiologically relevant prostanoid dose it was possible to observe that $\mathrm{AJC}$ proteins are differentially redistributed and this effect was concomitant to an impairment of the paracellular permeability in Caco- 2 cells. We demonstrated for the first time that $\mathrm{PGE}_{2}-\mathrm{EP} 1$ and EP2 receptor signaling regulates AJC disassembly through a mechanism that involves PKC, but not PKA or p38MAPK and reveals a critical role of claudin-1 in this event. Examination of these pathways can give a better understanding of the mechanisms concerning the loss of cell-cell adhesion and colon cancer progression and suggest new directions for potential therapy for this disease. 


\section{Methods \\ Antibodies and reagents}

Rabbit polyclonal anti-claudin-1 (JAY.8), occludin and ZO-1 (Z-R1) antibodies were purchased from Zymed Laboratories, Inc. (San Francisco, CA, USA). Mouse monoclonal anti-E-cadherin (36) was purchased from BD Biosciences (San Diego, CA, USA). The rabbit polyclonal anti-beta-catenin was purchased from Sigma Chemical Co. (St Louis, MO, USA). The secondary antibodies Alexa 488-conjugated goat anti-rabbit IgG and Alexa 546-conjugated goat anti-mouse IgG were purchased from Molecular Probe (Eugene, OR). Peroxidase-conjugated goat antirabbit IgG were obtained from Zymed Laboratories, Inc. (San Francisco, CA, USA) and peroxidase-conjugated goat anti-mouse IgG from Sigma. Prostaglandin $\mathrm{E}_{2}$, butaprost, sulprostone, 16, 16-dm PGE 2 and 17-phenyl trinor PGE were purchased from Cayman Chemical Company, (Ann Arbor, MI). SB203580, H-89 and Calphostin C were purchased from Biomol Res. Labs. Inc. (Plymouth Meeting, PA).

\section{Cell culture}

Caco-2 cells (ATCC, \# HTB-37, Rockville, MD, USA), a human colon cancer cell line were grown in Dulbecco Modified Eagle medium (DMEM) supplemented with $10 \%$ fetal bovine serum (FBS), penicillin G $(60 \mathrm{mg} / \mathrm{l})$ and streptomycin $(100 \mathrm{mg} / \mathrm{l})$ at $37^{\circ} \mathrm{C}$ in humidified atmosphere of $5 \% \mathrm{CO}_{2} /$ air. Culture medium was changed every $24 \mathrm{~h}$ to avoid nutrient depletion. All experiments were carried out when cells achieved confluence.

\section{$P G E_{2}$ and EP2 agonist treatments}

In order to determine the concentration of $\mathrm{PGE}_{2}$ in our experiments and on the basis of a kinetic study used by Pai et al [13], initially doses of 0.1 and $1 \mu \mathrm{M}$ were tested. We determined that $1 \mu \mathrm{M}$ was the concentration able to cause significant alterations on the AJC and was used in all subsequent experiments. Cell monolayers were serum-starved for $24 \mathrm{~h}$ then treated with $1 \mu \mathrm{M} \mathrm{PGE}_{2}$ for 15,30 and 60 min. When indicated, cells were pre-treated with specific inhibitors of p38 MAPK (10 $\mu \mathrm{M}$ SB203580), PKA $20 \mu \mathrm{M}$ (H-89) and PKC (500 nM Calphostin C), prior to $\mathrm{PGE}_{2}$ treatment.

The involvement of Prostaglandin $\mathrm{E}_{2}$ receptor EP subtypes was analyzed by using $1 \mu \mathrm{M}$ butaprost, EP2 agonist receptor, and the EP1 and EP3 agonist receptors: $1 \mu \mathrm{M}$ sulpros-

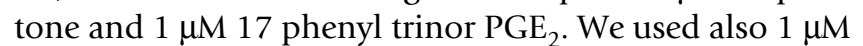
16, 16-dimethyl Prostaglandin $E_{2}\left(16,16-d m P_{2}\right)$, $\mathrm{PGE}_{2}$ analogous.

\section{Transepithelial Electrical Resistance (TER)}

It is well known that TER is an instantaneous measurement that evaluates the degree of tightness and paracellular flux across epithelium [1]. In order to determine TJ functionality after $\mathrm{PGE}_{2}$ and $\mathrm{EP}$ agonist receptor treatments, we performed TER analysis at different times of treatments. Caco-2 cells were grown on Transwell polycarbonate filters $0.4 \mu \mathrm{m}$ pore size (Costar, Cambridge, MA, USA) until confluent and treated as described above. TER values were determined using a Millicel-ERS system (Millipore Co, Billerica, MA, USA), with a 20A constant current. All TER values were normalized for the area of the filter $\left(0.6 \mathrm{~cm}^{2}\right)$ and were obtained after background subtraction (i.e., filter and bath solution). The results are expressed as percentage of total count (100\%) values of each treatment in relation to the control group of three independent experiments.

\section{Immunofluorescence Microscopy}

Cell monolayers were grown on sterile glass cover slips. After 15, 30 or 60 min of PGE2 treatment, cells were washed in PBS supplemented with $100 \mathrm{mM} \mathrm{CaCl} 2$ (PBS/ $\mathrm{CM}$ ), fixed and permeabilized with $100 \%$ methanol at $20^{\circ} \mathrm{C}$ for $20 \mathrm{~min}$. Subsequently, they were re-hydrated in $\mathrm{PBS} / \mathrm{CM}$, incubated in blocking solution $(0.2 \% \mathrm{BSA}$ in PBS/CM) for $1 \mathrm{~h}$ and overnight at $4^{\circ} \mathrm{C}$ with primary antibodies anti-ZO-1 (1:25), anti-claudin-1 (1:25), antioccludin (1:20), anti- $\beta$-catenin (1:2000) and anti-E-cadherin $(1: 100)$. Afterward they were incubated for $1 \mathrm{~h}$ at $37^{\circ} \mathrm{C}$ with the secondary antibodies Alexa 488-conjugated goat anti-rabbit IgG (1:500) or with Alexa 546-conjugated goat anti-mouse IgG (1:500). The cover slips were washed in PBS and mounted using n-propyl-gallate. Cell staining was detected using an Axiovert S 100 immunofluorescence microscope equipped with a CCD camera and KS 300 image analyzer (Carl Zeiss Inc., Jena, Germany).

\section{Transmission electron microscopy}

Cells were cultured on Transwell polycarbonate filters, and after treatments they were washed in PBS and fixed in a solution containing $2.5 \%$ glutaraldehyde, $1 \%$ paraformaldehyde, $0.8 \%$ sucrose and $2 \mathrm{mM} \mathrm{CaCl}_{2}$ in $0.1 \mathrm{M}$ cacodylate buffer, $\mathrm{pH}$ 7.4. Post-fixation was carried out in $1 \%$ osmium tetroxide $\left(\mathrm{OsO}_{4}\right)$ in cacodylate buffer, containing $0.8 \%$ potassium ferrocyanide and $5 \mathrm{mM} \mathrm{CaCl}_{2}$ for $45 \mathrm{~min}$. Subsequently, the cells were dehydrated with acetone and embedded in Epon resin. Ultrathin sections (60 $\mathrm{nm}$ ) were obtained, stained with uranyl acetate and lead citrate and observed in a Zeiss CEM-900 transmission electron microscope (Carl Zeiss Inc., Jena, Germany).

In order to determine TJ functionality, cell monolayers were washed in PBS, and fixed for $60 \mathrm{~min}$ on the apical side with the solution above indicated containing $6 \mathrm{mg} /$ $\mathrm{ml}$ of ruthenium red. Cells were washed three times with cacodylate buffer containing ruthenium red for $10 \mathrm{~min}$ each and post fixed with $1 \% \mathrm{OsO} 4$ and $6 \mathrm{mg} / \mathrm{ml}$ ruthenium red in cacodylate buffer for $45 \mathrm{~min}$. Subsequently, they were dehydrated in acetone series and embedded in 
Epon resin. Ultrathin sections were obtained, stained for 3 min with lead citrate only and observed in a Zeiss CEM900 transmission electron microscope (Carl Zeiss Inc.).

\section{Cell extraction in Triton $X-100$ and immunoblotting}

Samples were rinsed three times in PBS/CM and incubated for $20 \mathrm{~min}$ at $4^{\circ} \mathrm{C}$ in extraction buffer CSK: $50 \mathrm{mM}$ $\mathrm{NaCl}, 10 \mathrm{mM}$ piperazine-1, 4-bis (2-ethanesulfonic acid) (Pipes), pH 6.8, 3 mM MgCl${ }_{2}, 0.5 \%$ TritonX-100, $300 \mathrm{mM}$ sucrose, $1 \mathrm{mM}$ orthovanadate, $20 \mathrm{mM} \mathrm{NaF}$, and protease inhibitor cocktail (1:100, Sigma Chemical Co.) for 20 min at $4^{\circ} \mathrm{C}$. Cells were scratched from plates, homogenized and centrifuged at $10,000 \mathrm{~g}$ for $10 \mathrm{~min}$ at $4^{\circ} \mathrm{C}$. The supernatant corresponding to the TX-100 soluble fraction (cytosolic proteins) was removed and stored at $-20^{\circ} \mathrm{C}$. The pellet was resuspended in SDS buffer: $20 \mathrm{mM}$ Tris- $\mathrm{HCl}$, $\mathrm{pH} 7.5,5 \mathrm{mM}$ ethylenediamine-tetraacetic acid (EDTA), $2.5 \mathrm{mM}$ [ethylenebis(oxyethylenenitrilo)] tetra (EGTA), $1 \%$ sodium dodecyl sulfate (SDS) and boiled at $100^{\circ} \mathrm{C}$ for $10 \mathrm{~min}$. After centrifugation for $10 \mathrm{~min}$ at $10,000 \mathrm{~g}$ the supernatant, corresponding to the TX-100 insoluble fraction (cytoskeleton-linked proteins), was gently removed and stored at $-20^{\circ} \mathrm{C}$.

Equal amounts of protein $(30 \mu \mathrm{g})$, of cell fractions were electrophoretically separated by SDS-PAGE in $7.5 \%$ or $12 \%$ gels and transferred to nitrocellulose sheets using a semidry transfer cell (BioRad, Hercules, CA, USA) at $10 \mathrm{~V}$ for $60 \mathrm{~min}$. [47]. Then, the membranes were blocked for $1 \mathrm{~h}$ with TBS-T: $20 \mathrm{mM}$ Tris-HCl, pH 7.6, $137 \mathrm{mM} \mathrm{NaCl}$ and $0.1 \% \mathrm{v} / \mathrm{v}$ Tween 20 , containing 5\% low-fat dried milk and incubated overnight with primary antibodies: antioccludin (1:250), anti-E-cadherin (1: 2,000), anti-claudin-1 (1:250) and anti-ZO-1 (1:250). After washing, membranes were incubated for $1 \mathrm{~h}$ with peroxidase-conjugated goat anti-rabbit IgG $(1: 10,000)$ or peroxidaseconjugated goat anti-mouse IgG $(1: 40,000)$. Proteins were visualized using an enhanced chemiluminescence kit (Amersham Pharmacia Biotech, Buckingham, UK). Band images were quantified by optical density using the LabWorks 4.6 software (BIO RAD, Upland, CA).

\section{Statistical analysis}

Transepithelial Electric Resistance data were normalized to percentage and analyzed by one-way ANOVA followed by Bonferroni posttest for comparison between groups using GraphPad Prism version 4.0 for Windows (GraphPad Software, San Diego, CA). Densitometric analyses, which are comparisons between non-treated (which was normalized to 1) and treated samples, were carried out using Student's $t$-test. All values in text and figures are means \pm S.E.M of three independents experiments. Significantly different: * $(\mathrm{P}<0.05)$.

\section{Authors' contributions}

Author JAMD conceived of the study. MNT and JAMD designed and carried out all the experiments reported in the manuscript. BLD and WS participated in the design and analysis of $\mathrm{PGE}_{2}$ and ultrastructural experiments, respectively. JAMD participated in the coordination of the study and drafted the manuscript with input from all authors. All authors read and approved the final manuscript.

\section{Acknowledgements}

We thank all members of our laboratory for the constant discussion concerning the manuscript. This research was supported by Fundação Ary Frauzino para Pesquisa e Controle do Câncer (FAF), Ministério da Saúde (MS), Fundação Carlos Chagas Filho de Amparo à Pesquisa do Estado do Rio de Janeiro (FAPERJ) and Conselho Nacional de Desenvolvimento Científico e Tecnológico (CNPq).

\section{References}

I. Madara JL: Regulation of the movement of solutes across tight junctions. Annu Ver Physiol 1998, 60:143-159.

2. Mitic LL, Anderson JM: Molecular architecture of tight junctions. Annu Rev Physiol 1998, 60:121-142.

3. Anderson JM, Van Itallie CM, Fanning AS: Setting up a selective barrier at the apical junction complex. Curr Opin Cell Biol 2004, 16(2): 140-I 45.

4. Jamora $C$, Fuchs E: Intercellular adhesion, signalling and the cytoskeleton. Nat Cell Biol 2002, 4(4): EIOI-108.

5. Balda MS, Matter K: Epithelial cell adhesion and the regulation of gene expression. Trends Cell Biol 2003, 13:310-318.

6. Behrens J: Cadherins and catenins: role in signal transduction and tumor progression. Cancer Metastasis Rev 1999, I 8(I): I 5-30.

7. González-Mariscal L, Tapia R, Chamorro D: Crosstalk of tight junction components with signaling pathways. Biochim Biophys Acta 2008, $1778(3): 729-756$.

8. Itoh M, Furuse M, Morita K, Kubota K, Saitou M, Tsukita S: Direct binding of three tight junction-associated MAGUKs, ZO-I, ZO-2, and ZO-3, with the COOH termini of claudins. J Cell Biol 1999, I47(6): |35|-|363.

9. Balda MS, Matter K: The tight junction protein ZO-I and an interacting transcription factor regulate ErbB-2 expression. EMBO J 2000, 19:2024-2033.

10. Hata AN, Breyer RM: Pharmacology and signaling of prostaglandin receptors: multiple roles in inflammation and immune modulation. Pharmacol Ther 2004, 103(2): 147-166.

II. Shao J, Lee SB, Guo H, Evers BM, Sheng H: Prostaglandin E2 stimulates the growth of colon cancer cells via induction of amphiregulin. Cancer Res 2003, 63(17):5218-5223.

12. Han C, Michalopoulos GK, Wu T: Prostaglandin E2 receptor EP I transactivates EGFR/MET receptor tyrosine kinases and enhances invasiveness in human hepatocellular carcinoma cells. J Cell Physiol 2006, 207(I):26I-270.

13. Pai R, Soreghan B, Szabo IL, Pavelka M, Baatar D, Tarnawski AS: Prostaglandin E2 transactivates EGF receptor: a novel mechanism for promoting colon cancer growth and gastrointestinal hypertrophy. Nat Med Mar 2002, 8(3):289-293.

14. Yoshimoto T, Takahashi Y, Kinoshita T, Sakashita T, Inoue H, Tanabe $\mathrm{T}$ : Growth stimulation and epidermal growth factor receptor induction in cyclooxygenase-overexpressing human colon carcinoma cells. Adv Exp Med Biol 2002, 507:403-407.

15. Barbosa LA, Goto-Silva L, Redondo PA, Oliveira S, Montesano G, De Souza W, Morgado-Díaz JM: TPA-induced signal transduction: a link between PKC and EGFR signaling modulates the assembly of intercellular junctions in Caco-2 cells. Cell Tissue Res 2003, 3 I 2:3 | 9-331.

16. Buchanan FG, Wang D, Bargiacchi F, DuBois RN: Prostaglandin E2 regulates cell migration via intracellular activation of the epidermal growth factor receptor. I Biol Chem 2003, 278(37):3545I-35457. 
17. Krause W, DuBois RN: Eicosanoids and the large intestine. Prostaglandins Other Lipid Mediat 2000, 6 I(3-4): |45-16|.

18. Honda A, Sugimoto Y, Namba T, Watabe A, Irie A, Negishi M, Narumia S, Ichikawa A: Cloning and expression of a cDNA for mouse prostaglandin E receptor EP2 subtype. J Biol Chem 1993, 268:7759-7762.

19. Kitamura T, Itoh M, Noda T, Tani K, Kobayashi M, Maruyama T, Kobayashi K, Ohuchida S, Sugimura T, Wakabayashi K: Combined effects of prostaglandin E receptor subtype EPI and subtype EP4 antagonists on intestinal tumorigenesis in adenomatous polyposis coli gene knockout mice. Cancer Sci 2003, 94(7):6|8-62|.

20. Hawcroft G, Ko CW, Hull MA: Prostaglandin E2-EP4 receptor signalling promotes tumorigenic behaviour of HT-29 human colorectal cancer cells. Oncogene 2007, 26(2I):3006-3019.

21. Shoji Y, Takahashi M, Kitamura T, Watanabe K, Kawamori T, Maruyama T, Sugimoto $Y$, Negishi M, Narumiya S, Sugimura T, Wakabayashi K: Downregulation of prostaglandin E receptor subtype EP3 during colon cancer development. Gut 2004, 53(8): $1|5|-\mid 158$.

22. Grasa L, Arruebo MP, Plaza MA, Murillo MD: PGE(2) receptors and their intracellular mechanisms in rabbit small intestine. Prostaglandins Other Lipid Mediat 2006, 79(3-4):206-217.

23. Matlhagela K, Taub M: Involvement of EPI and EP2 receptors in the regulation of the $\mathrm{Na}, \mathrm{K}-\mathrm{ATP}$ ase by prostaglandins in MDCK cells. Prostaglandins Other Lipid Mediat 2006, 79(I2): $101-113$.

24. Narumiya S, Sugimoto Y, Ushikubi F: Prostanoid receptors: structures, properties, and functions. Physiol Rev 1999 79(4): I I 93-I 226.

25. Davies SP, Reddy H, Caivano M, Cohen P: Specificity and mechanism of action of some commonly used protein kinase inhibitors. Biochem J 2000, 35 I:95-105.

26. Klingler C, Kniesel U, Bamforth SD, Wolburg H, Engelhardt B, Risau W: Disruption of epithelial tight junctions is prevented by cyclic nucleotide-dependent protein kinase inhibitors. Histochem Cell Biol 2000, I | 3:349-36 I.

27. Blanco-Aparicio C, Torres J, Pulido R: A novel regulatory mechanism of MAP kinases activation and nuclear translocation mediated by PKA and the PTP-SL tyrosine phosphatase. Cell Biol 1999, I 47: I 129-1 I 36

28. Fujibe M, Chiba H, Kojima T, Soma T, Wada T, Yamachita T, Sawada $\mathrm{N}$ : Thr203 of claudin-I, a putative phosphorylation site for MAP Kinase, is required to promote the barrier function of tight junctions. Exp Cell Res 2004, 295:36-47.

29. Hull MA, Ko SC, Hawcroft G: Prostaglandin EP receptors: targets for treatment and prevention of colorectal cancer? Mol Cancer Ther 2004, 3(8): 1031 - 1039.

30. D' Souza T, Indig FE, Morin PJ: Phosphorylation of claudin-4 by PKCepsilon regulates tight junction barrier function in ovarian cancer cells. Exp Cell Res 2007, 3 I 3( I 5):3364-3375.

3I. Yuki T, Haratake A, Koishikawa H, Morita K, Miyachi Y, Inoue S: Tight junction proteins in keratinocytes: localization and contribution to barrier function. Exp Dermatol 2007, 16(4):324-330.

32. Musch MW, Walsh-Reitz MM, Chang EB: Roles of ZO-I, occludin, and actin in oxidant-induced barrier disruption. Am J Physiol Gastrointest Liver Physiol 2006, 290(2):G222-23I.

33. Han X, Fink MP, Delude RL: Proinflammatory cytokines cause no dependent and independent changes in expression and localization of tight junction proteins in intestinal epithelial cells. Shock 2003, 19:229-237.

34. Patrick DM, Leone AK, Shellenberger JJ, Dudowicz KA, King JM: Proinflammatory cytokines tumor necrosis factor-alpha and interferon-gamma modulate epithelial barrier function in Madin-Darby canine kidney cells through mitogen activated protein kinase signaling. BMC Physiol 2006, 6(2): I- 15.

35. Martin-Venegas R, Roig-Perez S, Ferrer R, Moreno JJ: Arachidonic acid cascade and epithelial barrier function during Caco-2 cell differentiation. J Lipid Res 2006, 47(7): | 4|6-|423.

36. Furuse M, Hata M, Furuse K, Yoshida Y, Haratake A, Sugitani Y, Noda T, Kubo A, e Tsukita S: Claudin-based tight junctions are crucia for the mammalian epidermal barrier: a lesson from claudinI-deficient mice. J Cell Biol 2002, I 56:1099-101 I.

37. Meyer zum Büschenfelde D, Tauber R, Huber O: TFF3-peptide increases transepithelial resistance in epithelial cells by mod- ulating claudin-I and $\mathbf{- 2}$ expression. Peptides 2006, 27(12):3383-3390.

38. Banan A, Zhang LJ, Shaikh M, Fields JZ, Choudhary S, Forsyth $C B$, Farhadi A, Keshavarzian A: Theta Isoform of protein kinase $C$ alters barrier function in intestinal epithelium through modulation of distinct claudin isotypes: a novel mechanism for regulation of permeability. I Pharmacol Exp Ther 2005, 313(3):962-982.

39. Matlhagela $\mathrm{K}$, Taub M: Involvement of EPI and EP2 receptors in the regulation of the $\mathrm{Na}, \mathrm{K}-\mathrm{ATP}$ ase by prostaglandins in MDCK cells. Prostaglandins Other Lipid Mediat 2006, 79(I2): $101-113$.

40. Narumiya S, Sugimoto Y, Ushikubi F: Prostanoid receptors: structures, properties, and functions. Physiol Rev 1999, 79(4): I 193-1226.

4I. Fujino $H$, Regan JW: Prostaglandin $E_{2}$ induced functiona expression of early growth response factor-I by $\mathrm{EP}_{4}$, but not $E P_{2}$, prostanoid receptors via the phosphatidylinositol 3kinase and extracellular signal-regulated kinases. J Biol Chem 2003, 278: $|2| 5|-| 2 \mid 56$

42. Tang $\mathrm{CH}$, Yang RS, Fu WM: Prostaglandin E2 stimulates fibronectin expression through EPI receptor, phospholipase $\mathrm{C}$, protein kinase $\mathrm{C}$-alpha, and c-Src pathway in primary cultured rat osteoblasts. J Biol Chem 2005, 280(24):22907-229l6.

43. Nishihara H, Hwang M, Kizaka-Kondoh S, Eckmann L, Insel PA: Cyclic AMP promotes cAMP-responsive element-binding protein-dependent induction of cellular inhibitor of apoptosis protein-2 and suppresses apoptosis of colon cancer cells through ERKI/2 and p38 MAPK. I Biol Chem 2004, 279(25):26|76-26|83.

44. Castellone MD, Teramoto H, Williams BO, Druey KM, Gutkind JS: Prostaglandin E2 promotes colon cancer cell growth through a Gs-axin-beta-catenin signaling axis. Science 2005 310(5753): I504-15I0

45. Misra UK, Pizzo SV: Coordinate regulation of forskolin-induced cellular proliferation in macrophages by protein kinase $\mathbf{A} /$ cAMP-response element-binding protein (CREB) and EpaclRap I signaling: effects of silencing CREB gene expression on Akt activation. J Biol Che 2005, 280(46):38276-38289.

46. Whittard JD, Akiyama SK: Positive regulation of cell-cell and cell-substrate adhesion by protein kinase A. J Cell Sci 200I, I | 4( I 8):3265-3272.

47. Towbin H, Staehelin T, Gordon J: Electrophoretic transfer of proteins from polyacrylamide gels to nitrocellulose sheets: procedure and some applications. Proc Natl Acad Sci USA 1979, 76:4350-4354.
Publish with BioMed Central and every scientist can read your work free of charge

"BioMed Central will be the most significant development for disseminating the results of biomedical research in our lifetime. "

Sir Paul Nurse, Cancer Research UK

Your research papers will be:

- available free of charge to the entire biomedical community

- peer reviewed and published immediately upon acceptance

- cited in PubMed and archived on PubMed Central

- yours - you keep the copyright

Submit your manuscript here

http://www.biomedcentral.com/info/publishing_adv.asp
BioMedcentral 